\title{
Introduction to "A Research Agenda for Examining the Role of Compensation Consultants in the Executive Pay Process"
}

\author{
Victor G. Devinatz ${ }^{1}$
}

Published online: 7 June 2016

(C) Springer Science+Business Media New York 2016

Wage inequality persists as a major problem confronting both industrial and post-industrial nations in the middle of the twenty-first century's second decade. While executive pay continues to grow at a rapid pace, most non-management private-sector employees' real wages (i.e. after adjusting wages for inflation) have remained stagnant or have even decreased over the last several decades. For example, according to the US Bureau of Labor Statistics, the average hourly wage of US non-managerial employees in September 2014 was \$20.67 which is essentially the same real wage that these employees earned in 1979. In fact, the highest average real wage of non-managerial employees in the private sector reached its apex in January 1973 when wages peaked at $\$ 4.03$ per hour which is equivalent to the buying power of \$22.41 in 2014 dollars. Conversely, in 2015, according to Economic Policy Institute statistics, Chief Executive Officers (CEOs) of the largest US companies earned three times more than they did in 1995 and at least 10 times more than in 1985. These exorbitant pay raises represented huge gains even when compared to those employees who are already earning very high wages. Such CEO pay increases have resulted in spillover effects which has led to increases in pay of other high-level executives and managers.

In this timely and well-written article, Dr. Peter Foreman, Associate Professor of Management at Illinois State University, and Dr. Jack Howard, Professor of Management at the University of Alabama - Birmingham, note that such explosive executive wage growth has occurred even when firms "have lost money and value." In order to understand this phenomenon, the authors argue that the role of compensation consultants, who have received insufficient scholarly attention in the research literature, must be rigorously analyzed to understand how executive pay is set. Foreman and Howard claim that the use of compensation consultants might help to explain how executive compensation continues to rise at a meteoric rate independent of company performance. Therefore, in order to sufficiently comprehend the role

Victor G. Devinatz

vgdevin@ilstu.edu

1 Department of Management \& Quantitative Methods, Illinois State University, Normal, IL 61790-5580, USA 
of compensation consultants in establishing executive compensation, Foreman and Howard present a number of theoretical viewpoints (while analyzing CEO pay in Verizon Communications) and provide explicit research recommendations for advancing the field's research.

I welcome employment relations scholars from around the globe to contribute future essays analyzing any employment-related topic from a wide variety of theoretical perspectives. Moreover, if any of the journal's readers would like to respond to particular essays or articles published in the "Perspectives" Section, please do not hesitate to contact me with your proposal. I welcome both practitioner-based and scholarly-based articles. I hope that you enjoy this essay and find it most illuminating. 